\title{
Evaluation OF THE CHALlENGES FACING ON- BOARD TRAINING IN TANZANIA: A DEMATEL MODELLING APPROACH
}

\author{
Erick P. Massami ${ }^{1}$ and Malima M. Manyasi ${ }^{2}$ \\ ${ }^{1}$ Department of Science and Management, Dar es Salaam Maritime Institute, \\ Dar es Salaam, Tanzania. \\ ${ }^{2}$ Department of Maritime Transport, Dar es Salaam Maritime Institute, \\ Dar es Salaam, Tanzania
}

\begin{abstract}
Effective OBT is part and parcel of quality MET provided by any maritime institute. To know the current status of the effectiveness of the OBT in Tanzania, the present study applies Extended DEMATEL Model to evaluate the challenges facing OBT in Tanzania. We firstly use expert opinions to identify the challenges and we then apply the Evaluation Model to rank the challenges facing OBT in Tanzania. The most prevalent challenges that are critical for effective OBT in Tanzania are identified and presented. The study reveals that the major challenges in descending order are Shortage of maritime simulators to complement OBT, Lack of ocean going vessels flying Tanzanian flag, and Lack of dedicated training ships. On the other hand, the minor challenges in descending order for effective OBT in Tanzania are Ineffective enforcement of Tanzania merchant shipping Act 2003, Decline of fleet owned and operated by SINOTASHIP, Shortage of merchant vessels undertaking coastal shipping in Tanzania waters, and Scarcity of qualified officers for effective OBT. The future extension of this study could be the analysis of the Tanzania Investment Policy in the Maritime Transport and Port Sector.
\end{abstract}

\section{KEYWORDS}

Maritime Education and Training, On-Board, DEMATEL Method, Evaluation, Challenges.

\section{INTRODUCTION}

The world trade is dependent on shipping [1]. Shipping is one of the most globalised industries in the world economy and the leading means of transport [2]. Effective and efficient shipping necessitates optimal supply of well-trained seafarers and competent onshore officers. Nonetheless, the labour market for seafarers continues to be unstable due to the imbalance between the supply of and demand for seafarers. More specifically, the shortage of seafarers, especially officers, is a continuing concern among key stakeholders in the global shipping industry [3]. Despite the recent global economic crisis, the demand for highly competent officers and ratings to man vessels around the world is still increasing [4]. Demirel and Erdogan [5] also state that there is currently severe shortage of well-qualified seafarers at different levels of seniority in the shipping industry. Consequently, Seafarers on-board ships may now be compelled to work longer hours, and sometimes receiving less vacation periods. Such practices may negatively affect work efficiency and more importantly may create circumstances where maritime safety and prevention of marine pollution is impaired. In addition, many research results reveal that about 80 percent of maritime accidents are attributed by human error and/or human factors. Thus, availability of qualified seafarers is a key element of shipping today which is of interest to all countries due to unbalanced seafarers' supply and demand. 
The supply of the highly qualified seafarers is a result of quality Maritime Education and Training (MET). More specifically, proper implementation of the Revised 2010 STCW Convention and Code requires MET Institutions to produce highly competent seafarers to man international vessels. Therefore the importance of MET cannot be understated taking into account that around 80 to 90 percent of maritime accidents are caused by human error. Thus, it is crucial for seafarers to be well educated and trained theoretically and practically to ensure safe, secure, clean and efficient operations for safety of life and property at sea. According to Albayrak and Ziarati [6] on-board training is very essential for entire seafarers of different kinds and plays an essential role in training and education of cadet officers. Maritime institutions with dedicated training ships and shipping companies with foreign going vessels usually offer the On-Board Training (OBT). Nonetheless, OBT opportunities for Tanzanian cadets have recently been reduced substantially. Thus, it is vital to explore challenges facing OBT in Tanzania and prioritizes the challenges for informed decision-making.

This paper is structured as follows: Section 2 presents previous relevant studies; Section 3 presents evaluation model based on Extended DEMATEL method; Section 4 presents application of the Extended DEMATEL model to evaluate the challenges facing OBT in Tanzania; Lastly, conclusions are given in Section 5.

\section{Previous Relevant Studies}

There are few studies worldwide that focus on On-Board Training (OBT). Manalo et al. [7] propose a study which focuses on the challenges encountered by Filipino Seafarers On-board using 80 respondents from Magsaysay Training Center and reveal that the most challenge onboard is homesickness followed by fatigue, family issues, discrimination, bad communication onboard and poor relationship in work place. Shen [8] describes how the STCW 95 imposes new requirements on shipping companies and states that more attention needs to be given to on- board training by Chinese shipowners. Albayrak and Ziarati [6] gives details how programmes for education and training for merchant navy cadets and officers are developed by TUDEV and their European partners and how these received international recognition. Nam [9] proposes a study based on the efficient improvement in the shipboard training. Noh et al. [10] present a study on improvement of efficient educational personnel and facility in the training ship. Yoon et al. [11] compares training and education in the on-board training of three countries including the United States, Japan and South Korea based on the STCW requirements. The literature review reveals that there are limited researches that investigate the challenges facing OBT worldwide. More specifically, none study appraises the challenges facing OBT in Tanzania regardless its position of having an internationally recognised Maritime Institute serving the East and Sub-Saharan African regions. Thus, it is vital to propose a study that investigates OBT challenges in the Tanzanian context.

We apply Extended DEMATEL Method to prioritize the challenges facing OBT in Tanzania. The DEMATEL approach has been proven to be an effective and efficient tool for determining interrelationship between criteria for real life problems. Bakir et al. [12] apply DEMATEL method to explore the critical determinants of environmentally oriented public procurement in Singapore. Kumar and Dixit [13] apply DEMATEL approach to prioritize the critical barriers for implementation of waste generation of electrical and electronic equipment. Gardas et al. [14] apply the DEMATEL approach to evaluate critical causal factors for post-harvest losses (PHL) in the fruit and vegetables supply chain in India. Trivedi [15] analyses complex interrelationships between determinants of shelter site selection for an effective disaster planning.

Bacudio et al. [16] apply DEMATEL to analyse barriers to implementing industrial symbiosis networks in Philippines. Li et al. [17] use DEMATEL method to analyse the in-depth of the 
interrelation among the core competences and cause effect of the IC design service company. Baruah et al. [18] use the DEMATEL method to rank the major cost sensitivities involved in Substation sitting in order of typical economic importance to overall decision-making. Shieh et al. [19] apply the DEMATEL method to evaluate the importance of seven major criteria and constructing the causal relations at Show Chwan Memorial Hospital in Changhua city, Taiwan. Gandhi et al. [20] propose a DEMATEL approach to develop a structural model for evaluating the influential factors in implementation of successful green supply chain management using empirical case study of an Indian manufacturing company. Tsai [21] applies the DEMATEL model to evaluate the criteria related to job satisfaction of research and development professionals in China's photovoltaic cell industry. Li and Mathiyazhagan [22] apply the DEMATEL approach to identify the influential indicators towards sustainable supply chain adoption among 35 leading auto-components manufacturing Small and Medium Enterprises (SMEs) in North India. Wu et al. [23] apply DEMATEL method to evaluate the importance of the criteria and construct the causal relationships among the criteria for employment service outreach in Taiwan. Hsu et al. [24] utilize the DEMATEL approach to recognise the influential criteria of carbon management in green supply chain for improving the overall performance of suppliers. Wu and Chang [25] apply DEMATEL method to identify critical factors in green supply chain management of electrical and electronic industries in Taiwan. Govindan and Chaudhuri [26] analyse the interrelationships between risks faced by third party logistics service providers (3PLs) in relation to one of its customers using DEMATEL method.

Unlike the previous studies, the current study presents an Extended DEMATEL Model (EDM) with one more step of determining the major and minor criteria. The classification of the criteria is achieved by defining the threshold value that is the arithmetic mean of the normalized weight of the criteria. The EDM is applied to evaluate the challenges facing OBT in Tanzania. The evaluation based on the Extended DEMATEL method is presented in the next section.

\section{Evaluation Model Based On Extended Dematel Method}

We develop an Extended DEMATEL based evaluation approach, which consists of the following sequential steps:

Step 1: Identify and Define Influential Factors of a Complex System. This is achieved by using the literature review, brainstorming and expert opinions.

Step 2: Establish an Assessment Scale. The scale is developed in order to determine the degree of influence between factors by performing pairwise comparisons of the factors. The relation between the linguistic operator of importance and its corresponding crisp value is shown in table 1.

Table 1. Assessment Scale.

\begin{tabular}{|l|c|c|c|c|l|}
\hline Score & 0 & 1 & 2 & 3 & \multicolumn{1}{|c|}{4} \\
\hline Degree of Influence & None (N) & Very Low (VL) & Low (L) & High (H) & $\begin{array}{l}\text { Very High } \\
(\text { VH) }\end{array}$ \\
\hline
\end{tabular}

Step 3: Establish the Initial Direct Relation Matrix. The Initial relation matrix $E$ is a $m \times m$ matrix which can be obtained by expert $r$ through pairwise comparison in which $e_{i j}$ represents the degree to which the criterion $i$ affects the criterion $\mathrm{j}$. The matrix $E$ is given by equation (1).

$$
E=\left[e_{i j}^{r}\right], \quad i, j \in\{1,2, \ldots m\} ; r \in\{1,2, \ldots R\}
$$

Step 4: Establish the Overall Relation Matrix 
The Overall Relation Matrix $\mathrm{G}$ is given by equation (2).

$$
G=\left[g_{i j}\right], \quad \forall i, j \in\{1,2, \ldots m\}
$$

Where $g_{i j}=\frac{1}{R} \sum_{r=1}^{R} e_{i j}^{r}, \forall i, j \in\{1,2 \ldots m\}$

Step 5: Normalize the Overall Direct Relation Matrix. The normalized overall direct relation matrix $N$ is obtained using equation (3) in which all elements of the matrix $N$ are between $[0,1]$ and all elements on the main diagonal are zeroes.

$$
N=\left(\frac{1}{\max _{1 \leq i \leq m} \sum_{j=1}^{m} g_{i j}}\right) G, \quad i \in\{1,2, \ldots m\}
$$

Step 6: Establish the total Overall Direct Relation Matrix $(F)$. The matrix $F$ is deduced from matrix $N$ as follows.

$$
F=\lim _{k \rightarrow \infty} \sum_{k=1}^{K} N^{k}
$$

Where $\lim _{k \rightarrow \infty} N^{k}=O$ and $O$ is a zero matrix of the same order as $N$.

Now,

$$
F=N(I-N)^{-1}
$$

Where $I$ is an identity matrix of the same order as $N$.

Step 7: Calculate the sum of the values in each row and column. This step entails summing the values of each row and column in the total overall direct relation matrix $F$, where $S R_{i}$ is the sum of the $i t h$ row and $S C_{j}$ is the sum of the $j t h$ column. The $S R_{i}$ and $S C_{j}$ represent both the direct and indirect influences between factors and are respectively given by equations (6) and (7).

$$
\begin{aligned}
S R_{i} & =\sum_{j=1}^{m} f_{i j}, \quad i \in\{1,2, \ldots m\} \\
S C_{j}=\sum_{i=1}^{m} f_{i j}, & j \in\{1,2, \ldots m\}
\end{aligned}
$$

Step 8: Computation of Prominence Values $\left(S R_{t}+S C_{t}\right), \forall t \in\{1,2 \ldots m\}$ and Relation Values $\left(S R_{t}-S C_{t}\right), \forall t \in\{1,2, \ldots m\}$.

Step 9: Determine the Importance of a Criterion

We adopt the formula proposed by Dalalah et al. [27] to calculate the importance of criteria which takes into account the values of $\left(S R_{t}+S C_{t}\right), t \in\{1,2 \ldots m\}$ and $\left(S R_{t}-S C_{t}\right), t \in$ $\{1,2 \ldots m\}$.

Thus,

$$
W_{t}=\sqrt{\left(S R_{t}+S C_{t}\right)^{2}+\left(S R_{t}-S C_{t}\right)^{2}}, \quad \forall t \in\{1,2, \ldots m\}
$$


Step 10: Compute the Overall Importance of a Criterion.

The overall importance of a criterion $t$ is the normalized weight, which is given by equation (9).

$$
W_{t}^{N}=\frac{W_{t}}{\sum_{t=1}^{m} W_{t}}, \quad \forall t \in\{1,2, \ldots m\}
$$

Where $W_{t}{ }^{N}$ is the normalized weight of a criterion $t$ that can be used in the decision making process.

Step 11: Determine Major and Minor Challenges.

Let the mean of the normalized weight be $(\bar{W})$ being the threshold value. Now $\bar{W}=0.1429$ i.e.

$$
\bar{W}=\frac{1}{N} \sum_{t=1}^{N} W_{t}^{N}, N \in\{7\}
$$

If $W_{t}^{N}<\bar{W}$, then $C_{t}$ is a major challenge. Otherwise, it is a minor challenge.

\section{Application of the Extended Dematel Model to Evaluate the Challenges Facing ObT in TANZania}

Experts' views in the maritime sector enable us identify seven main challenges facing optimal OBT in Tanzania. We describe each of these challenges in brief.

Ineffective enforcement of merchant shipping Act $2003\left(\mathbf{C}_{\mathbf{1}}\right)$ : Section 171 (1) of the Tanzanian merchant shipping act No. 21 of 2003 specifies that every shipowner of a Tanzanian registered vessel shall have an obligation to provide a minimum of two berths for the purposes of practical sea training of Tanzanian trainee seafarers on each registered vessel [28]. In addition, delay in the operationalization of the Maritime Education and Training Fund (MET Fund) poses more challenge to OBT. The MET Fund as specified by merchant shipping regulations 2011 is one of the dependable sources for financing OBT in Tanzania.

Shortage of merchant vessels undertaking a cabotage trade (coastal shipping) in Tanzanian waters $\left(\mathbf{C}_{2}\right)$ : There is a significant decline of vessels for Cabotage trade. This phenomenon is largely contributed by the recent improvement of road transport networks countrywide where most passengers prefer road transport to sea transport whereas most ship-owners and/or operators find investment in shipping not attractive as a result of reduced demand. Moreover, the collapse of the Tanzania Coastal Shipping Lines (TACOSHILI) fuelled further the shortage of vessels engaged in the coastal shipping.

Shortage of maritime simulators to complement OBT $\left(\mathbf{C}_{3}\right)$ : Using simulators for complementing practical training have advantages such as mitigation of risks related to actual systems operation, avoidance of high costs and avoidance of damage in case of an accident and/or injury. The simulation surroundings permits individual to be exposed to circumstances which the seafarer may rarely have the chance to face in real life where he is capable to integrate the technical knowledge with practical skills to handle the situation effectively. The most common simulators used by Maritime Institutes include Engine room simulator, Liquid cargo handling simulator, Dredging simulator, Ship handling simulator, Automatic Radar Plotting Aid (ARPA)/Radar simulator, Global Maritime Distress and Safety System (GMDSS) simulator, 
Automatic Identification System (AIS) simulator, and Electronic Chart Display and Information System (ECDIS) simulator.

Lack of dedicated training ships $\left(\mathbf{C}_{4}\right)$ : The ownership and operation of dedicated training ships mitigates the risks of missing OBT opportunities. However, only few Maritime Institutes have dedicated training ships. Specifically, Dar es Salaam Maritime Institute(DMI) since its establishment has never owned and/or operated a dedicated training ship. Thus, DMI cadets rely almost 100 percent for OBT training opportunities on shipping companies. Nonetheless, OBT opportunities have recently been reduced due to reduced manning levels as result of commercial pressures and increased automation level.

Decline of fleet owned and operated by SINOTASHIP $\left(\mathbf{C}_{5}\right)$ : Chinese-Tanzanian Joint Shipping Co. (SINOTASHIP) was established on $22^{\text {nd }}$ June 1967. It was the only marine company in East Africa with ocean going vessels carrying cargoes and connecting China, Southeast Asia and India to East Africa, Red Sea, Persian Gulf and Mediterranean regions. Ironically, SINOTASHIP currently owns only one Bulk Carrier vessel that is time chartered by COSCO. In the past time SINOTASHIP used to provide OBT opportunities for Tanzanian nationals.

Shortage of Ocean going vessels flying Tanzanian flag $\left(\mathbf{C}_{6}\right)$ : Very few vessels flying a Tanzanian flag are currently engaged in foreign trade routes. More specifically, none ocean going vessel flying Tanzanian flag is registered by the United Republic of Tanzania Shipping Register i.e. Tanzania Shipping Agencies Corporation (TASAC). It is now high time for the Tanzanian government to come up with a maritime policy that will attract many investors in the shipping business.

Scarcity of qualified officers for effective OBT $\left(\mathbf{C}_{7}\right)$ : The training can be impaired if offered by shore-based professionals who have been experts and as seafarers but are not able to transfer properly the knowledge to the trainees. The situation may worsen if the trainers who have no experience on the similar situations or using similar technology and equipment are imparting the training.

\subsection{Formulation of the Overall Relation Matrix}

We use the data collected from 10 experts (i.e. experienced mariners) in the Tanzanian maritime sector and establish the Initial Direct Relation Matrices from which we deduce the Overall Relation Matrix (G) as given by equation (10).

$$
G=\left[\begin{array}{lllllll}
0.0 & 3.1 & 1.9 & 3.5 & 3.0 & 3.4 & 2.2 \\
2.0 & 0.0 & 2.3 & 3.4 & 3.6 & 3.5 & 2.2 \\
2.9 & 3.3 & 0.0 & 3.4 & 3.5 & 3.7 & 3.6 \\
2.5 & 2.8 & 2.8 & 0.0 & 3.5 & 3.6 & 2.2 \\
2.2 & 2.5 & 2.3 & 3.6 & 0.0 & 3.6 & 2.7 \\
2.5 & 2.5 & 2.3 & 3.4 & 3.2 & 0.0 & 1.9 \\
2.3 & 2.2 & 2.5 & 3.1 & 2.6 & 2.8 & 0.0
\end{array}\right]
$$

The Overall Relation Matrix (G) reveals that $\max _{1 \leq i \leq m} \sum_{j=1}^{m} g_{i j}=20.4 \forall i, j \in\{1,2 \ldots 7\}$

\subsection{Formulation of the Normalized Overall Direct Relation Matrix}

We apply equation (3) to get the Overall Direct Relation Matrix (N) given by equation (11). 
International Journal of Business Information Systems Strategies (IJBISS) Vol.8, No.1/2/3, August 2019

$$
N=\left[\begin{array}{lllllll}
0.000 & 0.152 & 0.093 & 0.172 & 0.147 & 0.167 & 0.108 \\
0.098 & 0.000 & 0.113 & 0.167 & 0.176 & 0.172 & 0.108 \\
0.142 & 0.162 & 0.000 & 0.167 & 0.172 & 0.181 & 0.176 \\
0.123 & 0.137 & 0.137 & 0.000 & 0.172 & 0.176 & 0.108 \\
0.108 & 0.123 & 0.113 & 0.176 & 0.000 & 0.176 & 0.132 \\
0.123 & 0.123 & 0.113 & 0.167 & 0.157 & 0.000 & 0.093 \\
0.113 & 0.108 & 0.123 & 0.152 & 0.127 & 0.137 & 0.000
\end{array}\right]
$$

Thus,

$$
(I-N)^{-1}=\left[\begin{array}{ccccccc}
1.000 & -0.152 & -0.093 & -0.172 & -0.147 & -0.167 & -0.108 \\
-0.098 & 1.000 & -0.113 & -0.167 & -0.176 & -0.172 & -0.108 \\
-0.142 & -0.162 & 1.000 & -0.167 & -0.172 & -0.181 & -0.176 \\
-0.123 & -0.137 & -0.137 & 1.000 & -0.172 & -0.176 & -0.108 \\
-0.108 & -0.123 & -0.113 & -0.176 & 1.000 & -0.176 & -0.132 \\
-0.123 & -0.123 & -0.113 & -0.167 & -0.157 & 1.000 & -0.093 \\
-0.113 & -0.108 & -0.123 & -0.152 & -0.127 & -0.137 & 1.000
\end{array}\right]^{-1}
$$

\subsection{Formulation of the Total Direct Relation Matrix}

Since evaluating $N(I-N)^{-1}$ in Section 4.2 is a bit cumbersome, we use MATLAB software to deduce the total overall direct relation matrix $(\mathrm{F})$ as given by equation (13).

$$
F=\left[\begin{array}{ccccccc}
0.0000 & -0.0231 & -0.0086 & -0.0296 & -0.0216 & -0.0279 & -0.0117 \\
-0.0096 & 0.0000 & -0.0128 & -0.0279 & -0.0310 & -0.0296 & -0.0117 \\
-0.0202 & -0.0262 & 0.0000 & -0.0279 & -0.0296 & -0.0328 & -0.0310 \\
-0.0151 & -0.0188 & -0.0188 & 0.0000 & -0.0296 & -0.0310 & -0.0117 \\
-0.0117 & -0.0151 & -0.0128 & -0.0310 & 0.0000 & -0.0310 & -0.0174 \\
-0.0151 & -0.0151 & -0.0128 & -0.0279 & -0.0246 & 0.0000 & -0.0086 \\
-0.0128 & -0.0117 & -0.0151 & -0.0231 & -0.0161 & -0.0188 & 0.0000
\end{array}\right]
$$

\subsection{Computation of Prominence and Relation in the Total Overall Direct Relation Matrix}

We apply equations (6) and (7) respectively to get the sum of the values in each row $\left(S R_{t}\right)$ and column $\left(S C_{t}\right)$ in the total overall direct relation matrix $(\mathrm{F})$. These values are shown in table 2. The same table presents the Prominence $\left(S R_{t}+S C_{t}\right)$ and Relation $\left(S R_{t}-S C_{t}\right)$ of the 7 challenges.

Table 2. Prominence, Relation and Summation of the Values in Each Row and Column.

\begin{tabular}{|c|c|c|c|c|c|c|c|}
\hline$C_{t}$ & $C_{1}$ & $C_{2}$ & $C_{3}$ & $C_{4}$ & $C_{5}$ & $C_{6}$ & $C_{7}$ \\
\hline$S R_{t}$ & -0.1225 & -0.1226 & -0.1677 & -0.1250 & -0.119 & -0.1041 & -0.0976 \\
\hline$S C_{t}$ & -0.0845 & -0.1100 & -0.0809 & -0.1674 & -0.1525 & -0.1711 & -0.0921 \\
\hline $\begin{array}{l}S R_{t} \\
+S C_{t}\end{array}$ & -0.207 & -0.2326 & -0.2486 & -0.2924 & -0.2715 & -0.2752 & -0.1897 \\
\hline $\begin{array}{l}S R_{t} \\
-S C_{t}\end{array}$ & -0.038 & -0.0126 & -0.0868 & 0.0424 & 0.0335 & 0.0670 & -0.0055 \\
\hline
\end{tabular}

\subsection{Ranking of the Challenges Facing OBT in Tanzania}

We apply equations (8) and (9) respectively to deduce the importance of a challenge and the overall importance of the challenge as given in table 3. 
Table 3. The Weight and Rank of Each Challenge.

\begin{tabular}{|c|c|c|c|c|c|c|c|}
\hline$C_{t}$ & $C_{1}$ & $C_{2}$ & $C_{3}$ & $C_{4}$ & $C_{5}$ & $C_{6}$ & $C_{7}$ \\
\hline$W_{t}$ & 0.0380 & 0.0126 & 0.0868 & 0.0424 & 0.0335 & 0.0670 & 0.0055 \\
\hline$W_{t}{ }^{N}$ & 0.1330 & 0.0441 & 0.3037 & 0.1484 & 0.1172 & 0.2344 & 0.0192 \\
\hline Rank & 4 & 6 & 1 & 3 & 5 & 2 & 7 \\
\hline
\end{tabular}

From table 3, we reveal that $W_{t}{ }^{N}<\bar{W}, \forall t \in\{1,2,5,7\}$. This implies that the challenges leading to ineffective OBT in Tanzania to a less extent in descending order are Ineffective enforcement of Tanzania merchant shipping Act $2003\left(\mathrm{C}_{1}\right)$, Decline of fleet owned and operated by SINOTASHIP $\left(\mathrm{C}_{5}\right)$, Shortage of merchant vessels undertaking Coastal shipping $\left(\mathrm{C}_{2}\right)$ and Scarcity of qualified officers for effective OBT $\left(\mathrm{C}_{7}\right)$. Thus, all stakeholders are called to find solutions to overcome these challenges.

Likewise, $W_{t}^{N} \geq \bar{W}, \forall t \in\{3,4,6\}$ Thus, the challenges leading to ineffective OBT in Tanzania to a greater extent in ascending order are Lack of dedicated training ships $\left(\mathrm{C}_{4}\right)$, Shortage of ocean going vessels flying Tanzania flag $\left(\mathrm{C}_{6}\right)$, and Shortage of maritime simulators to complement OBT $\left(\mathrm{C}_{3}\right)$.

In order to produce many qualified and competent seafarers who can work in various offshore areas including oil and gas exploration and production platforms, the Tanzanian government should finance the purchase of a variety of maritime simulators for her maritime Institute. The proposed maritime simulators to be purchased for effective practical learning are Cargo handling simulator, Dredging simulator, Radar Simulator, Automatic Identification System (AIS) Simulator, Offshore Simulator, Dynamic Positioning Simulator, and Crane Operator Simulator. The government would recoup its investment capital by money brought by seafarers from abroad and spent in the country (Seafarers' remittances). In addition, the government would receive direct and indirect taxes from seafarers working in the domestic maritime sector.

Of all these major challenges, the shortage of ocean going vessels if overcome would substantially reduce the negative impact of other major challenges. In order for Tanzania to have many ocean going vessels flying her flag, the government should revisit its shipping investment policies. The attraction of private investors in the shipping business has far reaching economic benefits to the country including the creation of employment for seafarers, logistics service providers, bankers, insurers, brokers etc.; increase of foreign currency as freight tariffs are normally paid in United States Dollars; Cost saving resulting from the control of freight tariffs in liner shipping, creating confidence for local exporters to sell their goods under CIF terms and local importers to buy goods under FOB or Ex-Works terms and enhancing security in maritime supply chains. The implementation of such strategy and promotion of industrialization in a country in the long run would offset a balance of payments deficit.

The promotion of shipping investment in Tanzania calls the government to offer incentives designed to encourage investment in the Tanzanian shipping industry and to encourage the development of sustainable employment and skills opportunities for Tanzanian seafarers. Some of the proposed incentives could be: 
- Tonnage Tax Scheme [29]. Tonnage tax is a method for determining taxable income in which the taxable income is calculated as a lump sum depending on the size (net tonnage) of the ship, independent of the actual earnings (Profit or Loss). Normally, the taxable income as calculated by this method is considerably lower than the actual profit.

- Shipping Exempt Income Tax Incentive [30]. The main goal of the Shipping exempt income tax incentive is to attract existing vessels and newer vessels to be registered in Tanzania. Under this incentive, certain income generated from shipping activities of eligible vessels may be exempted from income tax.

- Accelerated Depreciation and Roll-Over Relief [30]. Accelerated depreciation means that the effective life of an eligible vessel is capped at say 10 years providing companies with a greater deduction in the earlier income years. Introducing a statutory capped life of shorter period of time provides an incentive for a younger fleet, which would have the additional benefit of incorporating new enhancements in technology and a reduced environmental impact.

- Seafarer Tax Offset [30]. A Tanzania company may be eligible for a refundable tax offset (a seafarer tax offset) for salary, wages and allowances (withholding payments) paid to Tanzanian resident seafarers who are employed to undertake overseas voyages on any eligible vessel. The seafarer tax offset is designed to stimulate opportunities for Tanzanian seafarers to be employed on overseas voyages and to gain maritime skills.

- Royalty Withholding Tax Exemption [30]. Payments made to non-residents by Tanzanian resident companies for the lease of eligible vessels on a bareboat basis may be exempted from royalty withholding tax. This aims to reduce the costs for Tanzanian shipping companies of securing foreign vessels on a bareboat basis, which is expected to increase the ability of Tanzanian operators to crew those vessels with Tanzanian workers.

We should note that the challenges facing OBT in Tanzania directly and/or indirectly affect the competitiveness of the local maritime institutions, seafarers, and the contribution of the maritime sector to the national Gross Domestic Product (GDP). Thus, all stakeholders are called to take the necessary corrective action that would lead to optimal OBT in Tanzania.

\section{CONCLUSIONS}

The present study applies the Extended DEMATEL Model (EDM) to prioritize the challenges facing OBT in Tanzania. The EDM is the DEMATEL Method with one more step of determining the major and minor criteria. The application of the EDM enables us to determine the impact of each challenge to the objective at hand. Lastly, the core challenges that are critical for effective OBT in Tanzania are revealed and presented. The findings show in descending order that the most prevalent challenges are Shortage of maritime simulators at local maritime institutes to complement OBT, Shortage of ocean going vessels flying Tanzania flag and Lack of dedicated training ships. These challenges if not well addressed can directly and/or indirectly affect the competitiveness of the local maritime institutions, seafarers, the contribution of the maritime sector to the national Gross Domestic Product, and the country's balance of payments. Thus, the government of Tanzania as a key stakeholder is called to take the necessary corrective actions that would lead to optimal OBT in the country. Investment in ocean going vessels flying the Tanzania flag can easily be achieved by attracting private investors in shipping business. The future extension of this study could be the analysis of the Tanzania Investment Policy in the Maritime Transport and Port Sector. 
International Journal of Business Information Systems Strategies (IJBISS) Vol.8, No.1/2/3, August 2019

\section{REFERENCES}

[1] M.E.Manuel, (2011) "Potential sociological impacts of unfair treatment of seafarers". The flagship journal of international shipping and port research, Vol.38, No. 1, pp. 39-49.

[2] M.Ljing, (2010)“Function Based Manning and Aspects of Flexibility". WMU Journal of Maritime Affairs, Vol.9, No. 1, pp. 121-133.

[3] T.T. Nguyen,H.Ghaderi, L.D. Caesar and S.Cahoon, (2014)“Current Challenges in the Recruitment and Retention of Seafarers: An Industry Perspective”. The Asian Journal of Shipping and Logistics, Vol.30, No. 2, pp. 217-242.

[4] A.M. Baylon and V. Santos, (2011)“The challenges in Philippine Maritime Education and Training”.International Journal of Innovative Interdisciplinary Research, Vol. 1, No. 1, pp. 34-43.

[5] E.Demirel and O.Erdogan, (2017) "New Technologies in Maritime Education and Training, Turkish Expriment”.Universal Journal of Educational Research, Vol.5, No.6, pp. 947-952.

[6] T.AlbayrakandR.Ziarati, (2010)“Training: Onboard and Simulation Based Familiarisation and Skill Enhancement to Improve the Performance of Seagoing Crew". Proceedings of International Conference on Human Performance at Sea HPAS 2010, Glasgow, Scotland, UK, June 16-18, pp. 1121.

[7] A.R.G.Manalo, N.R. Mercado, D.F.Paragas, J.C.C.Tenorio and J.C.Dotimas, (2015)“The challenges of Filipino Seafarers Onboard: Basis for Work life Balance”. LPU-Laguna Journal of International Tourism and Hospitality Management, Vol.3, No. 1, pp. 157-184.

[8] G.Shen, (1999)“The Impact of the STCW 95 on the Onboard Training Programs of Shipping Companies in China: Meeting the Challenge of Change. World Maritime University. Dissertation: 429”. [Online]. Available: http://commons.wmu.se/all_dissertations/429. [Accessed October 31, 2018].

[9] C.D.Nam, (1995)“A Study on the Efficient Improvement in the Shipboard Training”.Journal of the Korean Society of Marine Environment and Safety, Vol. 1, No. 2, pp. 96-97.

[10] B.S.Roh, J.G.Kang, S.K. Kim, Y.S.Park, I. Kim and S.T.Kim, (2010) "A Study on Improvement of Efficient Educational Personnel and Facility in the Training Ship". Journal of Navigation and Port Research, Vol. 34, pp. 615-621.

[11] D.Yoon,T.K.. Nam, J.B.Yim and Y.S.Ahn,(2012) "Comparison of Training and Education in the Training Ship”. International Association of Maritime Universities AGAII, pp. 9-19.

[12] S.Bakir, S. Khan,K.Ahsan and S.Rahman, (2018) "Exploring the critical determinants of environmentally oriented public procurement using the DEMATEL method". Journal of Environmental Management, Vol.225, pp. 325-335.

[13] A. Kumar and G.Dixit, (2018) "Evaluating critical barriers to implementation of WEEE management using DEMATEL approach”.Resources, Conservation and Recycling. Vol.131, pp. 101-121.

[14] B.B.Gardas, R.D.Raut, and B.Narkhede, (2018)“Evaluating critical causal factors for post-harvest losses (PHL) in the fruit and vegetables supply chain in India using the DEMATEL approach".Journal of Cleaner Production, Vol.199, pp. 47-61.

[15] A.Trivedi, (2018) "A multi-criteria decision approach based on DEMATEL to assess determinants of shelter site selection in disaster response".Internal Journal of Disaster Risk Reduction, Vol.31, pp. $722-728$. 
[16] L.R.Bacudio, M.F.D. Benjamin, R.C.P.Eusebio, S.A.K.Holaysan, M.A.B.Promentilla, K.D.S. Yu and K.B.Aviso, (2016)“Analyzing barriers to implementing industrial symbiosis networks using DEMATEL”.Sustainable Production and Consumption, Vol.7, pp. 57-65.

[17] Y.T.Li, Y.H.Yang, J.S. Kang and H.C.Yu, (2011)“Using DEMATEL method to explore the core competences and causal effect of the IC design service company: An empirical case study”. Expert Systems with Applications, Vol.38, No. 5, pp. 6262-6268.

[18] S.Baruah, S. Raj, A. Ray and S.Chakravorty, (2012)“Analysis of influencing factors for costs on Substation siting based on DEMATEL Method”. Procedia Engineering, Vol. 38, pp. 2564-2571.

[19] J.Shieh, H.H.Wu and K.K.Huang, (2010) "A DEMATEL method in identifying key success factors of hospital service quality”. Knowledge-Based Systems, Vol. 23, No. 3, pp. 277-282.

[20] S.Gandhi, S.K.Mangla, P. Kumar and D.Kumar, (2015)"Evaluating factors in implementation of successful green supply chain management using DEMATEL: A case study”. International Strategic Management Review, Vol. 3, No. 1-2, pp. 96-109.

[21] S.B.Tsai, (2018)“Using the DEMATEL model to explore the job satisfaction of research and development professionals in China's photovoltaic cell industry”. Renewable and Sustainable Energy Reviews, Vol.81, Part 1, pp. 62-68.

[22] Y. Li and K. Mathiyazhagan, (2018). "Application of DEMATEL approach to identify the influential indicators towards sustainable supply chain adoption in the auto components manufacturing sector”.Journal of Cleaner Production, Vol. 172, pp. 2931-2941.

[23] H.H.Wu, H.K. Chen and J.Shieh, (2010) "Evaluating performance criteria of employment service outreach program personnel by DEMATEL method”.Expert Systems with Applications, Vol.37, No. 7, pp. 5219-5223.

24] C.W. Hsu, T.C.Kuo, S.H. Chen and A.H.Hu, (2013)“Using DEMATEL to develop a carbon management model of supplier selection in green supply chain management". Journal of Cleaner Production, Vol. 56, pp. 164-172.

[25] H.H. Wu and S.Y.Chang, (2015)“A case study of using DEMATEL method to identify critical factors in green supply chain management”. Applied Mathematics and Computation, Vol. 256, pp. 394-403.

[26] K. Govindan and A.Chaudhuri, (2016)“Interrelationships of risks faced by third party logistics service providers: A DEMATEL based approach". Transportation Research Part E: Logistics and Transportation Review, Vol.90, pp. 177-195.

[27] D.Dalalah, M.Hayajneh and F.Batieha, (2011)“A Fuzzy Multi-Criteria Decision Making Model for Supplier Selection”. Expert Systems with Applications, Vol.38, No. 7, pp. 8384-8391.

[28] Tanzania Merchant Shipping Act 2003 (SI 2003/21). Available at: http://www.Saflii.org/tz/legis/num_act. (Accessed October 31, 2018).

[29] German Government,(2002) “Tonnage tax". [Online]. Available:

https://www.deutsche-flagge.de/en/financial-matters/tonnage-tax-1. [Accessed May 29, 2019].

[30] Australian Government, (2012) “Tax Incentives-Australian Shipping”. [Online]. Available: https://www.infrastructure.gov.au/maritime/business/tax_incentives/index.aspx. [Accessed May 29, 2019]. 


\section{Authors}

Erick P. Massami is currently a Senior Lecturer in Shipping and Logistics Studies at Dar es Salaam Maritime Institute, Tanzania. He holds a PhD in Logistics Engineering and Management from Dalian Maritime University, China. Dr. Erick P. Massami has published numerous research papers in various internationally recognized journals including International Journal of Business Continuity and Risk Management, Journal of Transportation Technologies, Advances in Decision Sciences, International Journal of Advanced Research in Artificial Intelligence, International Journal of Logistics Systems and Management, International Journal of Business Performance and Supply Chain Modelling, International Journal of Traffic and Transportation Engineering, International Journal of Emerging Technology and Advanced Engineering, and International Journal of Fuzzy Logic Systems. His research interests include Shipping and Logistics Management, Supply Chain Modelling and Optimization, Computational Intelligence, Transport Insurance, Economic Investment Planning, and Financial Investment Planning.

Malima M. Manyasi has a Master Degree in Information Technology from Hochschule Ostwestfalen-Lippe University of Applied Sciences, Germany. Currently he is working as an Assistant Lecturer at Dar es Salaam Maritime Institute, Tanzania. His research interests focus on Artificial Intelligence, System Modelling, Machine Learning, Maritime Transport technology and Data Mining.

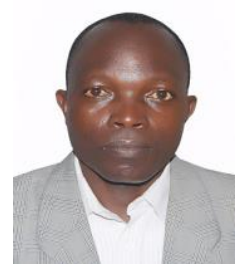

